\title{
Management of onion seed worm (Helicoverpa armigera) associated with onion seed crop in Swat valley of Khyber Pakhtunkhwa
}

\author{
Bashir Ahmad ${ }^{1 *}$, Walid Khan ${ }^{1}$, Ahmad-Ur-Rahman Saljoqi ${ }^{1}$, Shahid \\ Sattar $^{1}$, Hayat Zada ${ }^{2}$, Fazal Maula ${ }^{3}$ and Saddam Hussain ${ }^{1}$ \\ 1. Department of Plant protection, The University of Agriculture, Peshawar-Pakistan \\ 2. Agriculture Services Academy, Peshawar-Pakistan \\ 3. Agriculture Research Institute, North Mingora Swat-Pakistan \\ *Corresponding author's email: bashir.ahmad@aup.edu.pk \\ Citation \\ Bashir Ahmad, Walid Khan, Ahmad-Ur-Rahman Saljoqi, Shahid Sattar, Hayat Zada, Fazal Maula and Saddam Hussain. \\ Management of onion seed worm (Helicoverpa armigera) associated with onion seed crop in Swat valley of Khyber \\ Pakhtunkhwa. Pure and Applied Biology. Vol. 8, Issue 1, pp68-77. http://dx.doi.org/10.19045/bspab.2018.700165

\begin{tabular}{llll}
\hline \hline Received: 03/07/2018 & Revised: 25/09/2018 & Accepted: 04/10/2018 & Online First: 12/10/2018 \\
\hline
\end{tabular}

\section{Abstract}

Current research work was conducted during 2016 in Swat, Khyber Pakhtunkhwa to evaluate the efficacy of synthetic insecticides (Furadan-3G and Thimet-5G), botanical extracts (Azadirachta indica and Parthenium hysterophorus) and Trichogramma chilonis (Tricho-cards) in comparison with control against onion budworm in onion seed crop, Allium cepa. The statistical design used for experiment $1^{\text {st }}$ was Randomized Complete Block with 3 treatments having 3 replications, whereas $2^{\text {nd }}$ experiment was consisted of 4 treatments and 3 replications. In experiment- 1 , the lowest mean number of larvae of $H$. armigera was recorded in Furadan $\left(0.48\right.$ plant $\left.^{-1}\right)$ followed by Thimet $\left(0.50\right.$ plant $\left.^{-1}\right)$ and the highest was recorded in control plot $\left(0.56\right.$ plant $\left.^{-1}\right)$. In experiment-2 the lowest means number of larvae plant ${ }^{-1}$ was recorded in Trico-cards $(0.56)$ followed by $A$. indica (0.59) and Parthenium (0.61) whereas the highest were noted in control (0.75). The highest thousand seed weight $(8.00 \mathrm{~g})$ was obtained from Furadan treated plot followed by Thimet $(7.00 \mathrm{~g})$ and control $(1.67 \mathrm{~g})$ respectively. Significantly lowest seeds plant ${ }^{-1}$ was noted in control (618.8) which was statistically at par with Parthenium (812.7). The highest average yield was recorded in Furadan $(521.00 \mathrm{~kg} / \mathrm{ha})$ followed by Thimet $(512.00 \mathrm{~kg} / \mathrm{ha})$, Tricho-cards $(475.33 \mathrm{~kg} / \mathrm{ha})$ and control $(330.00 \mathrm{~kg} / \mathrm{ha})$. The maximum biological efficacy was reported in Furadan $(36.00 \%)$ followed by Parthenium (18.67\%). In lab research it was recorded that both Neem $5 \%$ and Parthenium 7\% were safe for Trichogramma chilonis. The use of Neem and Parthenium in combination with bio control agent is recommended for the IPM program.

Keywords: Allium cepa; Botanical extracts; Helicoverpa armigera; Pesticides; Trichogramma chilonis

Introduction

Onion, Allium cepa (Amaryllidaceae: Asparagales) is a biennial and cross- pollinated herbaceous winter vegetable [1]. There are different shapes, colors and tastes of onion. Bulbs of onion are flattened or 
torpedo in shape with red, yellow or white in color; It is used on daily basis in large amount [2]. It is a good source of micro-nutrients such as minerals, salts and vitamins [3]. Onion is the second largest vegetable in terms of world annual production after tomatoes [4]. Overall onion production in Pakistan during 2014-15 was recorded as 1,763.0 thousand tons on area of 135.1 thousand hectares. Similarly, onion production in Khyber Pakhtunkhwa in 2014-15 was recorded as 185.5 thousand tons on total area of 11.4 thousand hectare, in which the contribution of district Swat was 93.5 (000, tons) with an area of 3.8 thousand hectares respectively [5]. The onion crop is attacked by numerous pest species including insects as well as micro-organisms (Bacteria, Fungi and viruses) [6]. However, among all pest species the most devastating and threatening pest are onion thrips (Thrips tabaci) and onion budworm, (Helicoverpa armigera) [7]. Onion budworm is very active pest during the flowering stage which badly affects seed portion of the crop [8]. Similarly, $H$. armigera mostly attacks the fruiting part of the plant and also attack on the flowers and leaves of the plant as well. The adult moth of the budworm is characterized by fast, low level of flight takes an irregular path and eventually skip to other nearby plants. Forewings of Bud worms are attractive light brown while the hind wings are pale and have black scraps at the end. The female laid white spherical eggs singly at the top of plants with the size of about $(0.5 \mathrm{~mm})$. The eggs turn darken before hatching and hatched after seven days when they are laid. Caterpillars development is temperature dependent and full feed in about seven weeks, after the full maturity, they come down to the ground from plant and pupate in the soil [9]. Synthetic insecticides are being used efficiently against several insect pests but it has a lot of serious health and environmental problems [10]. Continues use of synthetic insecticides, produce a range of negative effects like effects on human health, toxic to non-target organisms and widespread environmental contamination, lead to a thorough search for natural enemies for the control of insect pest [11]. Using plant extracts to control insect pest is an ancient and effective pest control strategy. Botanicals insecticides are easily biodegradable less toxic [12], safer to environment, mankind and non-target organisms [13]. The chances of development of resistant in insect pests are very rear against botanical extracts [14]. At present, botanical insecticides are used in small quantity for insect pest control. It can be used under laboratory as well as in the field conditions as efficient crop protectants, especially in the developing countries [15]. Forty six families of flowering plants contain insecticidal activities [13]. Amongst plants kingdom, 384 plant species have antifeedants, 1,005 species hold insecticidal properties, 27 contain (growth inhibitors and attractants) and 297 enclose repellents which showed that plant kingdom is a large stockroom of potentially beneficial chemicals for insect pest management [14]. Many plant products have a wide range of insecticidal activity and are extensively reported for their antifeedants, toxic, ovicidal, repellent, antiovipositional and larvicidal activity [13].

Trichogramma chilonis is an efficient egg parasitoid belongs to the family Trichogrammatidae used widely in biological control program on a large scale against numerous Lepidopterous pests. $T$. chilonis adults are tiny wasps that laying egg inside the eggs of their host and make them kill.

The aim of the research work was to find out techniques for the better management of onion bud worn (Helicoverpa armigera) through use of botanical extracts (Neem and Parthenium) and Trichogramma chilonis (natural enemy) in comparison with synthetic 
insecticides (Furadan and Thimet) and control.

\section{Materials and methods}

The current study was carried out at Agricultural Research Institute Mingora, Swat to find out the efficiency of 2 different plant extracts (Azadirachta indica, Parthenium hysterophorus), 2 synthetic insecticides (Furadan, Thimet) and biological control agent, Trichogramma chilonis (Tricho-cards) in comparison with untreated check. Both experiments were replicated three times and Randomized Complete Block Design was used. Nursery of Swat-1 variety was sown and transplanted to experimental unit in December. The details of the treatments are below;

\section{Experiment 1}

T1: Furadan 3G (Granules), T2: Thimet 5G T3: Control

\section{Experiment 2}

T1: Neem Seed Extract, T2: Parthenium Extract, T3: Tricho-cards, T4: Control

\section{Field preparation}

Overall experimental field was prepared for seed sowing. Each replication was divided into 6 sub plots. Size of each sub plot was 12 square meters with total experimental area of 216 square meters. The space between each replication and each sub plot were one meter respectively. Row to row and Plant to plant distance was kept 2.5 and 1 feet respectively. Bulbs were transplanted and all the recommended agronomic practices were carried out with time to maintain the crop.

\section{Collection of plant extracts material}

For the collection of botanicals, Neem seed kernel was taken from open market while Parthenium leaves were collected from open fields of Newly Developmental Research Farm of Malakander, at The University of Agriculture Peshawar during 2016.

\section{Preparation of neem seed extract}

For preparation of neem seed extract the experimental procedure of [16] was followed with some modification. $500 \mathrm{~g}$ of Neem seed
(500 g) were dried and crushed with the help of grinder and was soaked in 1 liter of water (1 liter). After 24 hours the obtained solution was filtered from muslin cloth. The final filtrate was considered as a stock solution. From this stock solution further desired concentration were obtained by the following formula;

$\mathrm{C}_{1} \mathrm{~V}_{1}=\mathrm{C}_{2} \mathrm{~V}_{2}$

Where:

$\mathrm{V} 1=$ Volume to be taken from stock solution to make the desired concentration

$\mathrm{C} 1=$ Concentration of stock solution

$\mathrm{V} 2=$ Required volume

C2 $=$ Required concentration

\section{Preparation of Parthenium hysterophorus} extract

Parthenium leaves were dried in micro-wave oven and were crushed with the help of grinder. The crushed powder was weighed and was soaked in known amount of distilled water for 24 hour. After 24 hours the solution was filtrate from muslin cloth and the final filtrate was considered as stock solution and the desired concentration was prepared from the stock solution [16].

\section{Synthetic insecticides}

Both the insecticides, Furadan product of FMC United @8kg /acre and Thimet product of swat agro chemicals @8 kg /acre were bought from the local market in granules form. These granules were applied before earthing up for the onion bulb.

\section{Tricho-cards}

Tricho-cards were taken from SCRI Mardan and were applied @ 4 card/acre after flowering when infestation occurred [17].

Biological efficacy (Biological efficacy determination of selected treatments)

Infestation was recorded on the basis of mean number of $H$. armigera per plant. Biological efficacy was calculated by determining means of different treatments and subjected to following formula [18].

Biological efficacy $=\frac{\mathrm{A}-\mathrm{B}}{\mathrm{A}} \times 100$ 
Where

$A=$ Infestation in untreated plots

$\mathrm{B}=$ Infestation in Treated plots

\section{Data collection}

Data for experiment-1 was recorded 15 days after the granules application while for $2^{\text {nd }}$ experiment Pre-treatment data were recorded 24 hours before foliar application of chemical insecticides extracts, while the post treatment data was recorded after 24 hours, 48, 72 hours, 96 hours, 120 hours and onward with weekly intervals. Similarly, applications of treatments were repeated with specific intervals according to the requirement.

Data were collected on the following parameters:

1. Number of larvae per flower of plant.

2. Number of seed per flower of plant

3. Thousand seed weight

4. Plant height

5. Total yield per plot.

\section{Experiment 3}

The study was conducted to find out the effect of Neem @ 5\% and parthenium @ 7\% extracts on $T$. chilonis under laboratory conditions. For that purpose, the methodology of [19] was followed with some modifications. Complete randomized design (CRD) was used and treatments were replicated five times. A filter paper $(10 \mathrm{~cm}$ in length; $1 \mathrm{~cm}$ width) was dipped in the given concentration along with control (Water) for 30 second and was dried for 60 mints and placed in Petri dish. T. chilonis card ware subjected to each petri dish containing 5 eggs, and for food source to the inner side of each petri dish a honey streak honey solution was applied.

\section{Data collection}

The data were collected on the mean mortality of the natural enemy after 24,48 , 72 and 96 hours interval.

\section{Statistical analysis}

Randomized Complete Block Design was used for conducting the experiment including three replications. Data were examined by the
Statistical software (Statistix 8.1). Analysis of variance was constructed and Least Significant Difference (LSD) test was carried out for the comparison of means. For lab experiment the analysis of variance Statistix 8.1 was used under randomized completely design (CRD) and means were separated at $5 \%$ level of probability.

\section{Results}

To evaluate the effect of synthetic insecticides (Furadan, Thimet) and plant extracts (Neem 5\% and Parthenium 7\%) along with a biological control agent ( $T$. chilonis) against the onion bud worm $H$. armegira, a research work was conducted in Agriculture Research Institute Mingora Swat during 2016. The results are as followed;

\section{Effect of different chemical treatments on mean population of Onion bud worm larvae}

Data in table 1 revealed that after 24 hours the highest mean number of onion bud worm larvae were noted in control plots $(0.44)$ which was non-significant to Thimet (0.41) while showed significant difference to Furadan (0.39). The 48 hour data showed that Furadan (0.43) and Thimet (0.45) were significantly different from control plot (0.51) similar treatment effect on larvae of onion bud worm was recorded after 72 hour and 96 hours. Data recorded after 120 hours showed that lowest means number of onion bud worm were recorded in Furadan (0.47) which showed significant difference to Thimet (0.52) and control plot (0.57) while the treatment effect of week 1 was also similar to treatment effect of 120 hours. The data collected after week 2 revealed that lowest mean number of onion bud worm were noted in plot treated with Furadan $(0.60)$ followed by Thimet (0.63) and Control (0.67). The overall mean data showed that lowest mean number were recorded in plot treated with Furadan (0.48) which showed significant difference to Thimet $(0.50)$ and control (0.56). 
Table 1. Mean number of Helicoverpa armigera larvae after application of chemical insecticides

\begin{tabular}{|c|c|c|c|c|c|c|c|c|c|}
\hline Treatment & $\begin{array}{c}\text { Before } \\
\text { Data }\end{array}$ & $\begin{array}{c}\mathbf{2 4} \\
\text { hours }\end{array}$ & $\mathbf{4 8}$ hours & $\mathbf{7 2}$ hours & $\mathbf{9 6}$ hours & $\mathbf{1 2 0}$ hours & Week 1 & Week 2 & Mean \\
\hline Furadan & 0.53 & $0.39 \mathrm{~b}$ & $0.43 \mathrm{~b}$ & $0.43 \mathrm{~b}$ & $0.48 \mathrm{~b}$ & $0.47 \mathrm{c}$ & $0.53 \mathrm{c}$ & $0.60 \mathrm{~b}$ & $0.48 \mathrm{c}$ \\
\hline Thimet & 0.50 & $0.41 \mathrm{ab}$ & $0.45 \mathrm{~b}$ & $0.46 \mathrm{~b}$ & $0.47 \mathrm{~b}$ & $0.52 \mathrm{~b}$ & $0.58 \mathrm{~b}$ & $0.63 \mathrm{~b}$ & $0.50 \mathrm{~b}$ \\
\hline Control & 0.47 & $0.44 \mathrm{a}$ & $0.51 \mathrm{a}$ & $0.54 \mathrm{a}$ & $0.55 \mathrm{a}$ & $0.57 \mathrm{a}$ & $0.63 \mathrm{a}$ & $0.67 \mathrm{a}$ & $0.56 \mathrm{a}$ \\
\hline LSD & & $\mathrm{NS}$ & 0.05 & 0.06 & 0.06 & 0.04 & 0.05 & 0.03 & 0.02 \\
\hline
\end{tabular}

Means followed by similar letters within columns are non-significantly different @ 5\% level of probability

\section{Effect of different treatments on mean} population of Onion bud worm larvae

Table 2 data shows mean number of larvae per plant after the application of different treatments. After 24 hours the lowest mean number of larvae per plant was noted in Neem treated plot (0.48) which showed statistically no significant difference ( $\mathrm{P}>0.05)$ with Parthenium (0.49) and Trichocards (0.52). The highest mean numbers of larvae were recorded in control (0.60) which was statistically significant from rest of treatments. After 48 hours the lowest mean number of larvae was recorded at Neem $(0.52)$. The highest no of larvae were observed at control (0.64) followed by Tricho-cards (0.56) and Parthenium (0.53). Data recorded after 72 hours revealed that treatment Tricho-cards $(0.46)$ had the lowest mean number and significantly different from rest of treatments. The control showed maximum number of larvae per plant (0.69), while the remaining treatment showed no significant difference with each others. Data recorded after 96 hours indicated that the control (0.74) has highest number of larvae which showed significant difference from rest of treatments. The minimum number of larvae per plant (0.51) were noted in Trichocards followed by Neem (0.57) and Parthenium (0.60). Data recorded after day 120 hours revealed that significantly maximum mean number of larvae were noted in control plot $(0.81)$ while the remaining treatment showed no significant different amongst each other. Similar treatment effect was recorded after week 1. Data collected after week 2 showed that control were nonsignificant to Parthenium while showed a significant difference from rest of treatments whereas the parthenium was found nonsignificant to Tricho-cards (0.71) and Neem (0.74. Mean data (overall) showed that the lowest mean numbers of larvae were recorded in Tricho-cards (0.56), followed by Neem (0.59) and Parthenium (0.61) which were statistically at par with each other. The highest mean numbers of larvae were recorded in control plot (0.75).

\section{Effect of different treatments on yield parameters}

Table 3 data revealed that the highest thousand seed weight $(8.00 \mathrm{~g})$ was obtained from Furadan. The treatment Tricho-cards $(6.33 \mathrm{~g})$ is statistically at par with Thimet $(7.00 \mathrm{~g})$ and Neem $(4.67 \mathrm{~g})$ and parthenium $(4.00 \mathrm{~g})$. The lowest thousand seed weight was recorded in control plot $(1.67 \mathrm{~g})$. The plant height data stated that maximum plant height was observed in Furadan $(77.20 \mathrm{~cm})$ which is significantly different from the rest of treatments followed by Tricho-cards $(71.80 \mathrm{~cm})$, Thimet $(71.17 \mathrm{~cm})$ and Neem $(68.10 \mathrm{~cm})$. The lowest plant height were recorded in parthenium $(65.57 \mathrm{~cm})$ followed by control $(61.80 \mathrm{~cm})$. Data regarding number of seeds per umbel showed that significantly lowest seeds per plant were noted in control (618.8) followed by parthenium (812.7) and neem (890.8). The maximum numbers of seeds per umbel were noted in plot treated with Furadan (1132.0) which showed no significant difference with Thimet (1059.1) and Tricho-cards (1047.9). 
Yield data showed that the highest total yield were noted in Furadan (521.00 kg/ha) which was statistically at par with Thimet $(512.00$ $\mathrm{kg} / \mathrm{ha}$ ) followed by Tricho-cards (475.33 $\mathrm{kg} / \mathrm{ha})$, Neem (425.33 kg/ha) and parthenium $(397.33 \mathrm{~kg} / \mathrm{ha})$ whereas the Tricho-cards showed no significant difference with Neem, Furadan and Thimet whereas, significantly different from parthenium. The lowest total yield was noted in control plot (330.00 $\mathrm{kg} / \mathrm{ha}$ ).

Table 2. Mean number of Helicoverpa armigera larvae after application of different treatments

\begin{tabular}{|c|c|c|c|c|c|c|c|c|c|}
\hline Treatment & $\begin{array}{c}\text { Before } \\
\text { Data }\end{array}$ & $\begin{array}{c}\mathbf{2 4} \\
\text { hours }\end{array}$ & $\begin{array}{c}\mathbf{4 8} \\
\text { hours }\end{array}$ & $\begin{array}{c}\mathbf{7 2} \\
\text { hours }\end{array}$ & $\mathbf{9 6}$ hours & $\mathbf{1 2 0}$ hours & Week 1 & Week 2 & Mean \\
\hline Neem & 0.80 & $0.48 \mathrm{~b}$ & $0.52 \mathrm{~b}$ & $0.55 \mathrm{~b}$ & $0.57 \mathrm{bc}$ & $0.60 \mathrm{~b}$ & $0.66 \mathrm{~b}$ & $0.74 \mathrm{~b}$ & $0.59 \mathrm{~b}$ \\
\hline Parthenium & 0.75 & $0.49 \mathrm{~b}$ & $0.53 \mathrm{~b}$ & $0.56 \mathrm{~b}$ & $0.60 \mathrm{~b}$ & $0.63 \mathrm{~b}$ & $0.69 \mathrm{~b}$ & $0.79 \mathrm{ab}$ & $0.61 \mathrm{~b}$ \\
\hline Trico cards & 0.78 & $0.52 \mathrm{~b}$ & $0.56 \mathrm{~b}$ & $0.46 \mathrm{c}$ & $0.51 \mathrm{c}$ & $0.56 \mathrm{~b}$ & $0.61 \mathrm{~b}$ & $0.71 \mathrm{~b}$ & $0.56 \mathrm{~b}$ \\
\hline Control & 0.65 & $0.60 \mathrm{a}$ & $0.64 \mathrm{a}$ & $0.69 \mathrm{a}$ & $0.74 \mathrm{a}$ & $0.81 \mathrm{a}$ & $0.87 \mathrm{a}$ & $0.87 \mathrm{a}$ & $0.75 \mathrm{a}$ \\
\hline LSD & & 0.072 & 0.072 & 0.073 & 0.062 & 0.091 & 0.084 & 0.092 & 0.071 \\
\hline
\end{tabular}

Means followed by similar letters within columns are non-significantly different @ 5\% level of probability

Table 3. Mean of different yield parameters after treatments application

\begin{tabular}{|c|c|c|c|c|}
\hline Treat & $\begin{array}{c}\text { Thousand Seed } \\
\text { Weight (g) }\end{array}$ & Plant Height (cm) & $\begin{array}{c}\text { Number of seed per } \\
\text { umbel }\end{array}$ & Average Yield (kg/ha) \\
\hline Furadan & $8.00 \mathrm{a}$ & $77.20 \mathrm{a}$ & $1132.0 \mathrm{a}$ & $521.00 \mathrm{a}$ \\
\hline Thimet & $7.00 \mathrm{ab}$ & $71.17 \mathrm{c}$ & $1059.1 \mathrm{ab}$ & $512.00 \mathrm{a}$ \\
\hline Neem & $4.67 \mathrm{bc}$ & $68.10 \mathrm{~d}$ & $890.8 \mathrm{~b} \mathrm{c}$ & $425.33 \mathrm{bc}$ \\
\hline Parthenium & $4.00 \mathrm{~cd}$ & $65.57 \mathrm{e}$ & $812.7 \mathrm{~cd}$ & $397.33 \mathrm{c}$ \\
\hline Tricho-cards & $6.33 \mathrm{abc}$ & $71.80 \mathrm{~b}$ & $1047.9 \mathrm{ab}$ & $475.33 \mathrm{ab}$ \\
\hline Control & $1.67 \mathrm{~d}$ & $61.80 \mathrm{f}$ & $618.8 \mathrm{~d}$ & $330.00 \mathrm{~d}$ \\
\hline L.S.D & 2.96 & 0.31 & 208.73 & 65.56 \\
\hline
\end{tabular}

Means followed by same letters within columns are non-significantly different at $5 \%$ level of significance

Biological efficacy of different treatments against onion bud worm larvae

Data presented in table 4 showed percent biological efficacy of different treatments. Means of all the treatments were calculated and subjected to Abbot Formula. The highest biological efficacy $(36.00 \%)$ was recorded in
Furadan followed by Thimet (33.33 \%) which is in close proximity with Furadan. The lowest percent biological efficacy over control was shown by parthenium (18.67\%) which was significantly different from Furadan, these were followed by treatment Neem $(21.33 \%)$ and Tricho-cards $(25.33 \%)$.

Table 4. Biological efficiency of different treatments using Abbot Formula

\begin{tabular}{|c|c|c|}
\hline Treatment & Means & \% Biological efficacy \\
\hline Furadan & 0.48 & $\mathbf{3 6 . 0 0} \%$ \\
\hline Thimet & 0.50 & $\mathbf{3 3 . 3 3} \%$ \\
\hline Neem & 0.59 & $\mathbf{2 1 . 3 3 \%}$ \\
\hline Parthenium & 0.61 & $\mathbf{1 8 . 6 7} \%$ \\
\hline Tricho-cards & 0.56 & $\mathbf{2 5 . 3 3 \%}$ \\
\hline Control & 0.75 & \\
\hline
\end{tabular}

\section{Effect of Neem and Parthenium concentrations on mean mortality of $T$. chilonis}

Data presented in table 5 indicated that after
24 hours highest mortality caused by Neem $5 \%$ (0.67) which showed no significant difference to control (0.33) and parthenium $7 \%$ concentration $(0.67)$. After 48 hours all 
the three treatments were non-significant to each other. Data recorded after 72 hours indicated that the highest mean mortality were recorded in Neem $5 \%$ (3.00) which is significant from Control (2.33) and showed no significant difference to parthenium $7 \%$ (2.67). Data recorded after 96 hours the highest mean mortality was noted in Neem $5 \%$ (4.00) followed by parthenium $7 \%$ (3.67) and control (3.33).

Table 5. Mean mortality of Trichogramma chilonis in Parthenium and Neem concentrations at different time interval

\begin{tabular}{|c|c|c|c|c|}
\hline \multirow{2}{*}{ Concentration } & \multicolumn{4}{|c|}{ Duration } \\
\cline { 2 - 5 } & $\mathbf{2 4}$ hours & $\mathbf{4 8}$ hours & $\mathbf{7 2}$ hours & $\mathbf{9 6}$ hours \\
\hline Neem 5\% & $0.67 \pm 0.00$ & $1.50 \pm 0.22$ & $3.00 \pm 0.00 \mathrm{a}$ & $4.00 \pm 0.00 \mathrm{a}$ \\
\hline Parthenium 7\% & $0.67 \pm 0.21$ & $1.50 \pm 0.22$ & $2.67 \pm 0.21 \mathrm{ab}$ & $3.67 \pm 0.21 \mathrm{ab}$ \\
\hline Control (water) & $0.33 \pm 0.21$ & $1.33 \pm 0.21$ & $2.33 \pm 0.21 \mathrm{~b}$ & $3.33 \pm 0.21 \mathrm{~b}$ \\
\hline LSD & NS & NS & 0.52 & 0.52 \\
\hline
\end{tabular}

Means followed by same letters in columns are non-significantly different at $5 \%$ level of significance

\section{Discussion}

Over all mean data showed that the lowest mean numbers of larvae were recorded in Furadan (0.48) that was not significantly different as compared to Thimet (0.50). The average mean number of larvae showed that Tricho-cards (0.56), Neem (0.59) and Parthenium (0.61) were statistically at par with each other. The highest mean numbers of larvae were recorded in control plot (0.75). Our current findings are in line with [20] who used different treatments for the control $H$. armigera and reported that insecticides were more effective followed by neem seed extract. Seven different chemicals were evaluated by [21] for the management of $H$. armigera in chick pea crop and found chemical insecticide indoxacarb14.5 SC@ $0.5 \mathrm{ml} / 1$ the most productive in managing the $H$. armigera larval population and obtain maximum yield which also support our findings. The outcome of our research work was in contrast with [22] who observed Furadan less effective against sucking pest. Our findings are strongly supported by [23, 24]. Effectiveness of botanical extracts also reported by [25] in managing pest of tomato crop. The significance of neem seed kernel extract due to its repellency or antifeedants were also previously report by [26] and concluded that it's due to the deterency of neem plant extracts to insect pests. Our findings are supported by [27] they reported the bio extracts efficacy lasts up to 10 days. Outcomes of [28] are in contrast with our findings who evaluate botanicals efficacy for the control of Helicoverpa armigera and non target natural enemies in Chickpea (Cicer arietinum L) and found NSKE effective. Efficacy of neem based extracts against Helicoverpa armigera on sunflower crop reported by [29] and observed that the biopesticides gradually reduced $H$. armigera population as compared with synthetic insecticides. Our results are also supported by [30] who applied different chemicals against $H$. armigera and reported Tracer (Spinosed (a) $60 \mathrm{ml}$ ) effective in field as well as in laboratory as compared to Arrive. The natural enemies Trichogramma chilonis egg parasitoid showed fluctuation in management of the pest at different time interval but were significantly better after week 2 compared with control. Management techniques for the control of $H$. armigera reported by [31] and suggested that all the strategies in integrated form were effective. The treatment Trichogramma along with Habrobracon hebetor was fruitful and control about $97 \%$ followed by endosulfan which control was about $75 \%$. Numerous management strategies determined by [32] for 
management of $H$. armigera and sort out that all the management strategies were better than control. They find out all the strategies effective in comparison with control plot. Trichogramma@16 cards having 400-500 eggs per card in sugar cane crop at different location tested by [17] and reported significant results of controlling the pest and pest damage reducing. Botanical extract Parthenium hysterophorus also proved effective in managing the pest population and showed significant differences with other treatments. The treatment $P$. hysterophorus showed significant difference with control plot at $2^{\text {nd }}$ week but statistically at par with rest of treatments. The findings of [33] are in support with our research work he used different plant extracts against $H$. armigera and reported that parthenium extract cause $69 \%$ percent mortality and $59 \%$ reduction in weight in comparison with control plot. $H$. armigera larvae 100 percent mortality was reported by [34] in petroleum ether extracts of $P$. hysterophorus. The highest yield parameters were obtained from the crop treated with chemical insecticides followed by Tricho-cards and Neem. Different chemicals were used by [21] for the management of $H$. armigera and recorded maximum yield in crop treated with chemical insecticide. The results of [35] are in contrast with us they reported highest yield in plot treated with $T$. chilonis and Neem.

The maximum percent biological efficacy of $(36.00 \%)$ was noted in plots treated with Furadan followed by Thimet with biological efficacy of $(33.33 \%)$, Tricho-cards (25.33 $\%)$ Neem $(21.33 \%)$, whereas the minimum percent biological efficacy was noted in Parthenium extract (18.67\%). The outcomes of [21] are in conformity with us they applied seven different insecticides for the control of $H$. armigera at field condition and found Indoxacarb $14.5 \mathrm{SC}$ the most fruitful with a biological efficacy of $(95.83 \%)$ and $(100 \%)$ over control. Our research work are against with the findings of [31] who conducted a research work at cotton field on integrated control of bollworm Helicoverpa armigera and reported about $97.57 \%$ mortality and $0.95 \%$ fruit infestation with Bacillus thuringiensis var. Kurstaki.

To check the affinity of Neem and Parthenium extracts with natural enemies, a lab study was designed and effect was checked against adult of parasitoid wasp, Trichogramma chilonis. It was find out that neem were highly toxic after 24, 48 and 96 hours interval, while parthenium was less toxic to natural enemies. Our results are in contrast with finding of [36] who reported $A$. indica extracts less toxic to coccinellid larvae. Significant effect of A. calamus extracts by [29] had reported against adult Trichogramma pretiosum and they also indicated that mortality depend upon concentration if the concentration increases the mortality increases. Our results are supported by [37] who also reported maximum toxicity of higher parthenium concentration against natural enemies.

\section{Conclusion}

It is concluded that among the used treatments, Furadan was the most effective synthetic pesticide to manage Helicoverpa armigera in term of mean population, biological efficacy and yield. In botanicals, Neem extract (5\%) was more effective than parthenium extract (7\%). Parthenium extract was found less toxic as compared to neem against the Trichogramma chilonis and therefore, due to its safety against $T$. chilonis and efficacy against the $H$. armigera, it is recommended to be used in the IPM program. Further investigation is needed to evaluate its efficacy in field conditions.

\section{Author's contributions}

Conceived and designed the experiments: B Ahmad, W Khan \& F Maula, Performed the experiments: B Ahmad, W Khan \& F Maula, Analyzed the data: AUR Saljoqi, S Sattar \& $\mathrm{H}$ Zada, Contributed materials/ analysis/ 
tools: F Maula \& H Hayat, Wrote the paper: B Ahmad, W Khan \& S Hussain.

\section{References}

1. Dawar NM, Wazir FK Dawar M \& Dawar SH (2007). Effect of planting density on growth and yield of onion varieties under climatic condition of Peshawar. Sarhad J Agric 23(4): 911-912.

2. Haynes L (2009). Determination of an Economical Optimal Organic Control of Onion Maggots in Allium crop, Project Number: FNC0 4: 497.

3. Muhammad Z, Jilani MS Mehwish K Waseem MK Khattak AM Rahim A \& Wahab A (2009). Comparison of different weed management practice in onion (Allium cepa L.) under agro climatic condition of Dera Ismail Khan, Pakistan. Pak J Weed Sci Res 15(1): 45-51.

4. Zeb J, Khan Z Nabi G \& Nawaz K (2007). Marketing margins for onion in Swat. Sarhad J Agric 23(3): 793-801.

5. Agriculture statistics of Pakistan (201415) annual book. http://www.mnfsr.gov.pk.

6. Arkhipove GE (1984). Pests of Onion. Zashch. Rastenii. 10: 53.

7. Atwal, AS (1976). Agriculture Pests of India and South East Asia. Kiliani Publishers Delhi. 502.

8. Singh H (1984). Household and kitchengarden pests-principals and practices Kalyani Publishers, New Delhi. 420.

9. Mangano P, Michael P \& Hardie D (2001). Management of native budworm in Pulse and Canola crops in south-west of Western Australia. Department of Agriculture and Food Western Australia 15: 184-185.

10. Kim DI, Park JD Kim SG Kuk H Jang MS $\&$ Kim SS (2005). Screening of some crude plant extracts for their acaracidal and insecticidal efficacies. $J$ Asia Pacific Entomol 8(1): 93-100.

11. Vincent C, Philogene BJR \& RegnaultRoger C (2005). Biopesticides of Plant Origin. Lavoisier, Paris, France.

12. Behal SR (1998). Effect of some plant oils on the olfactory responses of rice moth, Corcyra cephalonica, Stainton. Ann Plant Protec Sci 6(2): 146-150.

13. Zhu BC, Henderson $G$ Chen F Fei $H$ \& Laine RA (2001). Evaluation of vetiver oil and seven insect-active essential oils against the formosan subterranean termite. (Coptotermes formosanus). J Chem Ecol 27(1): 523-531.

14. Govindarajan M, Mathivanan T Elumalai K Krishnappa K \& Anandan A (2011). Ovicidal and repellent activities of botanical extracts against Culex quinquefasciatus, Aedes aegypti and Anopheles stephensi (Diptera: Culicidae). $J$ Trop Biomed 1(1): 43-48.

15. Isman, $M B$ (2008). Botanical insecticides: for richer, for poorer. Pest Manag Sci 64(1): 8-11.

16. Satti AA, Ellaithy ME \& Mohamed AE (2010). Insecticidal activities of neem Azadirachta indica A. Juss seeds under laboratory and field conditions as affected by different storage durations. J Agric Biol 1(5): 1001-1008.

17. Mustafa G, Ghani A \& Sikandar Z (2006). Performance of Trichogramma for the control of sugarcane borer in former fields at various districts of Punjab (Pakistan). Pak Sug J 21 (5): 5-7.

18. Abbot WS (1925). A method of computing the effectiveness of an insecticide. $J$ Econ Entomol. 18(2): 265-267.

19. Heather N \& Hassan E (2012). Effects of oil extract of Leptospermum petersonii FM (Bailey) on Plutella xylostella and its parasitoid Trichogramma pretiosum Riley. J Econ Entomol 105(4): 1379-1384.

20. Karabhantanal SS \& Awaknavar JS (2013). Bio intensive approach for the management of tomato fruit borer, Helicoverpa armigera (Hubner). Pest. Manag. Hort Ecosyst 18(2): 135-138.

21. Yogeeswarudu B \& Venkata Krishna K (2014). Field studies on efficacy of novel insecticides against Helicoverpa armigera (Hubner) infesting on Chickpea. $J$ Entomol Zool Studies 2(4): 286-289.

22. Raqib A, Javed HI \& Khan I (1993). Field 
evaluation of some insecticides against tobacco budworm, Heliothis armigera (Hb.), and peach aphid, Myzus persicae (Sulz.). Pak $J$ Agric Engin Vet Sci (Pakistan).

23. Seal DR, Jha VK \& Liu TX (2010). Potential of various strains of Entomopathogenic Nematodes in combination with Insecticides for suppression of Black Cutworm, Agrotis ipsilon (Lepidoptera: Noctuidae). Ann PI Protec Sci 18(2): 293-300.

24. Zahid MA, Sarker MAI Islam MM Hossain MA \& Begum MR (2009). Effects of seed treatment and soil application with some insecticides on stem fly and pod borers on mungbean. Bangladesh J Agric Res 34(2): 303-311.

25. Gajanana TM, Krishna Moorthy PN Anupama HL Raghunatha R \& Prasanna Kumar GT (2006). Integrated pest and disease management in tomato: An economic analysis. Agric Econ Res Rev 19(2): 269-280.

26. Gilani G, (2001). Neem the wonder tree. 37.

27. Rao NV, Reddy AS \& Reddy PS (1990). Relative efficacy of some new insecticides on insect pests of cotton. Indian J Plant Prot 18(1): 53-58.

28. Lulie N \& Raja N (2012). Evaluation of certain Botanical preparations against African Bollworm, Helicoverpa armigera Hubner (Lepidoptera: Noctuidae) and Non Targeted Organisms in Chickpea, Cicer arietinum. J Biofertil Biopest 3(5): 1-6.

29. Khuhro SA, Lanjar AG and Solangi AW (2014). Efficacy of Neem Kernal Powder and Neem Oil against Helicoverpa armigera on Sunflower Crop. J Natural Sci Res 4(7): 45-49.

30. Ahmed S, Zia K \& Shah N (2004). Validation of chemical control of gram pod borer, Helicovepa armigera (Hub.) with new insecticide. Int J Agric Biol 6(6): 978979.

31. Darvish MT, \& Ghasemi BK (2011). An evaluation control of cotton bollworm Helicoverpa armigera (hub.) in the northern Iran. Int Res J App Basic Sci 2(5): 203-208.

32. Gul F \& Saeed MQ (2007). Role of root borer (Emmalocera depressella) in sugarcane ratoon crop failure and their integrated control in NWFP. Pak Sug $J$ 22(1): 82-87.

33. Gopalakrishnan S, Rao GR, Humayun P, Rao VR, Alekhya G, Jacob S \& Rupela O (2011). Efficacy of botanical extracts and entomopathogens on control of Helicoverpa armigera and Spodoptera litura. African J Biotechnol 10(73): 16667-16673.

34. Janardhan RS, Chitra KC, Kameswara RP \& Subramaniyam RK (1999). Antifeedant and insecticidal properties of certain plant extracts against Helicoverpa armigera. $J$ Insect Sci 5: 163-164.

35. Usman M, Inayatullah M Usman A Sohail K \& Shah SF (2012). Effect of egg parasitoid, Trichogramma chilonis, in combination with Chrysoperla carnea and neem seed extract against tomato fruitworm, Helicoverpa armigera. Sarhad J Agric 28(2): 253-257.

36. Hoelmer KA, Osborne LS \& Yokomi RK (1990). Neem's potential in pest management programs, in JC Locke and RH Lawson (eds), Effects of neem extracts on beneficial insects in greenhouse culture. Proc USDA Workshop, USDA, ARS, ARS-86, Beltsville, MD pp 100-5.

37. Mehmood, N (2016). M. Sc (Hons). In vitro management of the diamondback moth (Plutella xylostella) through different concentrations of Parthenium and Neem extracts. Uni Agri Pesh pp 22. 